\title{
The Levels of Militarizationin Southeast Asia
}

\author{
Posma Sariguna Johnson Kennedy ${ }^{1}$, Santi Lina Siregar ${ }^{2}$ \\ \{posmahutasoit@gmail.com ${ }^{1}$, santilina@gmail.com ${ }^{2}$ \} \\ Faculty of Economy and Business Universitas Kristen Indonesia, Jl.Mayjen Sutoyo No.2, Jakarta, \\ Indonesia ${ }^{1}$, Faculty of Economy Universitas Kristen Maranatha, Jl. Prof.Drg. Surya Sumantri No.65, \\ Bandung, Indonesia ${ }^{2}$
}

\begin{abstract}
In this paper we want to look at the potential threats between countries in the Southeast Asian region by looking at the militarization degree. This paper is a part of defense economics in which the militarization degree will be seen from the economic side.The research is a descriptive method by using graphics form. The index will be analyzed to see the militarization degree of countries in Southeast Asia through the Global Military Index. Indonesia has the highest national income and the largest population. However, Indonesia still has a militarization degree that below the average in Southeast Asia. For that reason, Indonesia needs to increase its military budget with heavy weaponry programs, as well as the addition of military personnel reserves.
\end{abstract}

Keywords: Defense economy, Militarizationlevel, Natural balance of power, Potential traditional threat.

\section{Introduction}

\subsection{Background}

The special characteristic of traditional or external threats is come from outside the country which state is as an actor with heavy and modern weapon. According to traditional view, the security definition is closely related to military power. In order to be secure, strong military capability must be owned or allied with other countries to face various threats. This is what distinguishes from internal threats, where the enemy is not a state, but groups or person, with the simple weapon. In more recent developments, the spectrum of "threats" is extended. The extension of this concept is from the formulation of the United Nation which requires the concept change of "security against" from "emphasis on national security" to greater emphasis on "people security".

This study focuses on traditional threats. Although Indonesia does not have traditional enemies, but the lack of awareness or guard against traditional/external threats can be very dangerous. Even weak defenses can be the entrance to internal conflicts caused by foreign influences. A weak defense will reduced state authority in the international arena. The diplomacy for the country interests does not have strong compressive power. In addition, dominance, violations, foreign infiltration and others will enter into the country easily,because of the weakness. To deal with, the state should not hope from other countries, but must based on its own strength.

There are countries that have been physically conflicted, some are aggressive, some doing arms races. But some, feeling no threat at all. Traditionally, external threats are derived from 
asymmetric military forces between countries where today the concept has evolved into a natural balance of power. The modern threat is always associated with military forces that are proportional to the economy of a country. The militarization level that is too high and disproportionate to the economic capacity is perceived as a threat to the surrounding countries. We expect the economic power with healthy competition is as a national power. Who has economy power can control international relations in its strategic environment [1].

The suitable conditions for Indonesia in the strategic environment of Southeast Asia, is to treat the threat variables as potential or latent in assumption of natural balance of power. By that assumption, the novelty of this study is, the threat is not seen deals with military power only, but also from the economic forces. A country with a good economy will be able to buy good armaments, improve human resources and develop cutting-edge technology. Based on this description, the authors are interested to see the potential threats between countries in the Southeast Asian region by looking at the militarization degree of these countries. This paper is part of defense economics in which the militarization degree will be seen from the economic side, not only from its defense budget, the number of soldiers and heavy weaponry.

\subsection{Literature Review}

Militarization is the policy of a country in achieving its national goals by increasing the national power that is directed through the development of military force [2].

The existence of a state power relative to their neighbors strength will be considered in the calculation of threats. The magnitude of traditional/external threats is very sensitive to the existence power of each state relative to the theirneighbors strength. This magnitude assumes, the greater of the nation's relative capability will be more influence the political and military on its strategic environment. The distribution of these capabilities is asymmetric among the countries will be forming threats and pressures between them.

The differences of balance of power between countries can provide threat perceptions. Lebovic \& Ishaq defines a threatening situation as an asymmetric power distribution between countries that creates a threat and tension or escalation between them [3]. Thus this threatening situation can be expressed as a concept of relative power. But this asymmetrical form of power is seen from a different angle depending on what motive underlies this condition [3].

Chatterjee explains, the classical balance of power distribution is greatly influenced by the military power of a country, the number of soldiers, the amount of weaponry and technology that is reflected in its military budget [4].

This concept actually has several weaknesses. The actual adjustment of power does not run automatically, but it depends on the ability of actors or statesmen to see and interpret it appropriately. In specific cases it is very difficult to know whether the changes in the resource are influenced by the actors or not. This model does not take into account the goals and motivations of these countries, as not all countries use their influence to continue to improve resources and power to gain influence in international politics [5].

A clear commitment between countries can provide the impossibility of war. However, asymmetric information can provide the possibility of war, even if no change in power distribution occurs. Technological developments have an important effect on the formation of a country's behavior based on the calculation of benefits and costs. If a country feels the benefits are greater than the risk, the occurrence of war will has higher proability, vice versa.

Since the World War II complete, as Virmani noted, the world changed dramatically. The concept of "balance of power" gradually transformed into a "natural balance of power" in 
which the economic magnitude becomes the basis. This balance will also be called "stable balance" if it shows a natural balance. "Natural balance of power" is the ideal of peace in the world. Natural balance of power is defined as a state's responsible attitude in increasing their relative potential power in proportion with respect to internationalization and global rights. The built system is expected to create a peaceful economic competition between countries. Within his own country, there is no competition between dimensions, both economic and military [6]. Virmani explained that stable conditions in the "natural balance of power" will be realized if [6]:

a. The relative military strength is proportional to the economic power. Military posture is formed in a rational and legitimated quantity.

b. Aggressive military development can be identified and immediately isolated by the international/global system before there are victims who fall due to the aggressiveness.

c. Changes in economic power are relatively directly related to a country's position in international relations. The strongest are those with greater economic power.

d. International cooperation in the field of economic cooperation is very intensive which increases the collective strength, so as to increase the cost for a country if it wants to aggressive.

Treverton explain, national power is the total of national resources. The country's capability containers are transformed or converted through state-level processes into usable strengths. Actual processes within this framework are focused on very critical factors. These factors are what constitute a national power [7].

Green explains, a strategic balance between nations is possible only when there is system and resource stability. In order to maximize national power, it may be assumed that a nation needs a strong military as well as a robust economy. Moreover, without a strong economy, a nation will lack the resources to build a powerful military [8].

\section{Methods}

This research method is descriptive by using statistics that are translated in the form of graphs. The balance of power is proportionately captured by different military capabilities across countries in the region through indexes. In accordance with the concept of "natural balance of power" that developed, where the desired competition is a healthy competition in the economic field. The asymmetry of the militarization balance of a country is a potential threat faced by other countries.

The Global Military Index (GMI) is used to view this situation. An index overview through graphs will be analyzed to see the militarization degree of countries in Southeast Asia. GMI is an index that describes the capacity of armaments or the militarization level within a country. The index is published by the Institute for Strategic International Studies (IISS) funded by the German Government. This GMI is used to see the militarization degree of of ASEAN countries as Indonesia's strategic environment. The GMI is divided into three categories, namely military expenditure, personnel, and heavy weapons [8].

Figures for military spending are compiled from the database of the Stockholm Peace Research Institute (SIPRI). Data on gross domestic product (GDP) taken from the International Monetary Fund (IMF). The data on health expenditure used from the data base of the World Health Organization (WHO). All data on military personnel was compiled from 
IISS. Population size figures taken from the Vital Statistics Report of the United Nations (UN). Data on the number of physicians from the World Health Organization (WHO). Data on weapons holdings was collected by Bonn International Center for Conversion (BICC) from different sources, mainly from IISS.

The indicators for GMI with their weighted can be seen in the table below:

Table 1. Indicators of Global Military Indeks [2].

\begin{tabular}{llc}
\hline Category & \multicolumn{1}{c}{ Indicator } & $\begin{array}{c}\text { Weigh- } \\
\text { ted }\end{array}$ \\
\hline Military & $\begin{array}{l}\text { Military spending in relation to } \\
\text { Expenses }\end{array}$ & 5 \\
& $\begin{array}{l}\text { The relation ofmilitary budget to } \\
\text { health spending } \\
\text { The relation of military and } \\
\text { paramilitary personnel to total } \\
\text { population. }\end{array}$ & 3 \\
Military & $\begin{array}{l}\text { The relation of military reserves to } \\
\text { total population } \\
\text { Personnel }\end{array}$ & 2 \\
& $\begin{array}{l}\text { The relation of military and } \\
\text { paramilitary personnel to physicians } \\
\text { The relation of heavy weapons in } \\
\text { relation to total population }\end{array}$ & 2 \\
\hline
\end{tabular}

\section{Result and Discussion}

Each country has different situations in their strategic international environment. For example, in Southeast Asia is certainly different from the Middle East and Europe as well as Latin America. Lebovic \& Ishaq share two conditions of how the state acts to face the threats in accordance with the circumstances of their strategic environment, namely [2] :

a. First, a country will seek to have high military capability aggressively regardless of the proportion of inter-state power. The country will make itself the strongest in its region.I

b. Second, threats are treated as latent rather than active threats. Threats perceived as pressure. When the perception of political pressure and tension changes, it will affect the level of military spending. The country is also more emphasis on fundamental forces that cause views against threats more implicit than explicit. The fundamental threat is seen from national security that potentially affecting economic policy and defense development.

Traditional threats in Southeast Asia environment are still so natural, that they called potential or latent threats. This threat is not only related to military power, but also economic power. Of all models described above, the most suitable situation in the strategic environment of Southeast Asia is by assuming a "natural balance of power", where the state balance of power in the region is still stable. The situation facing a country will be reflected in the military budget policy in building its defense force based on its economic strength. For Indonesia, the result of the generated economy and the population must be maintained through a strong defense.

Here are the GDP, and the number of population in Southeast Asia: 


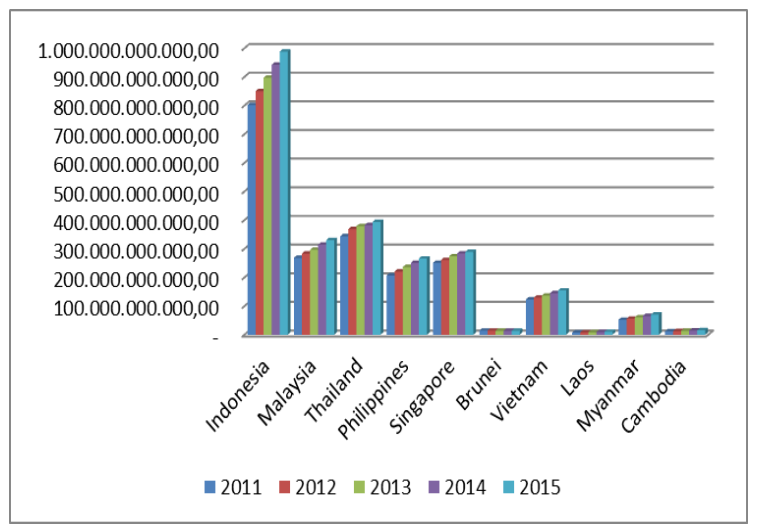

Fig. 1. The Gross Domestic Product (GDP, constant 2010 US\$) in Southeast Asia(Period of 2011-2015).

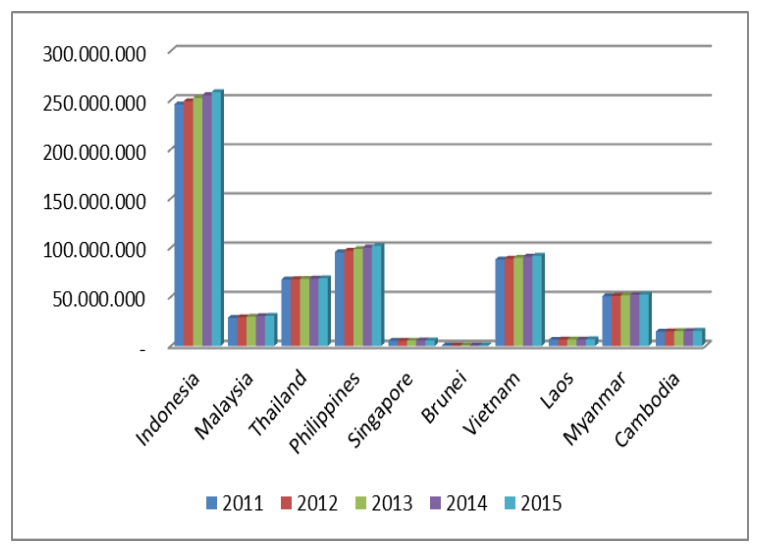

Fig. 2. Number of Population in Southeast Asia (Period of 2011-2015).

From the figures above, Indonesia has the highest national income and the largest population. Thus it is natural that Indonesia should have a large armed force. Countries in strategic environments will naturally rather than a dilemma security. Indonesia needs to safeguard its wealth and its inhabitants properly.

To see the militarization degree in Southeast Asia, indexed by looking at the economic and population power, as in the following figure: 


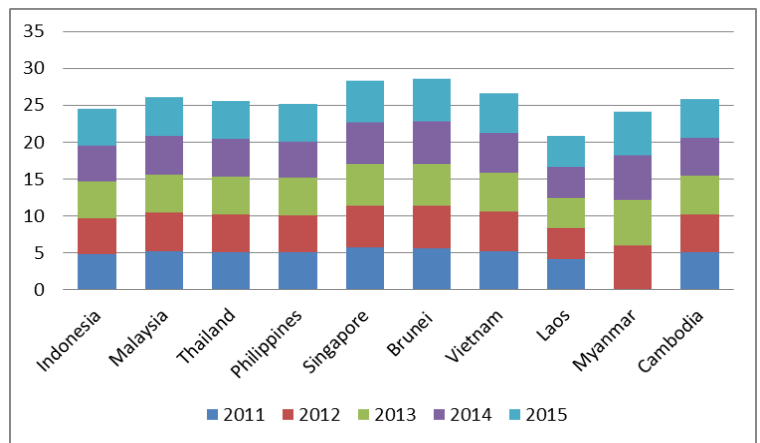

Fig. 3. Military Expenditures Indeks (Period of 2011-2015).

Source: Data Processing from Bonn International Center for Conversionhttps://www.bicc.de/

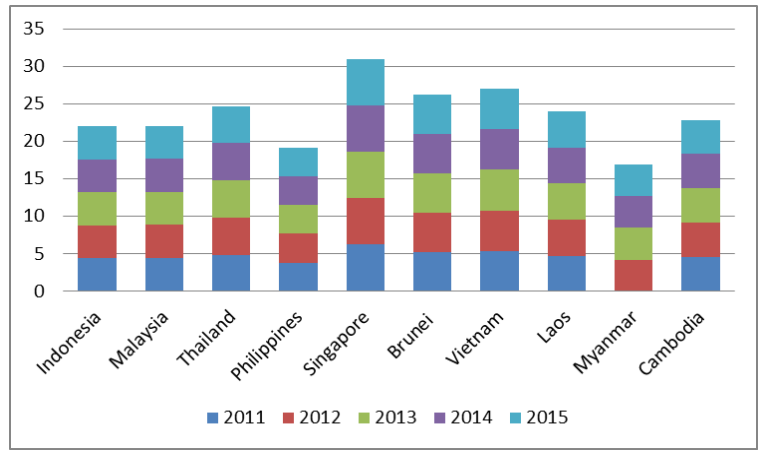

Fig. 4. Military Personal Index (Period of 2011-2015).

Source: Source: Data Processing from Bonn International Center for Conversion(https://www.bicc.de/)

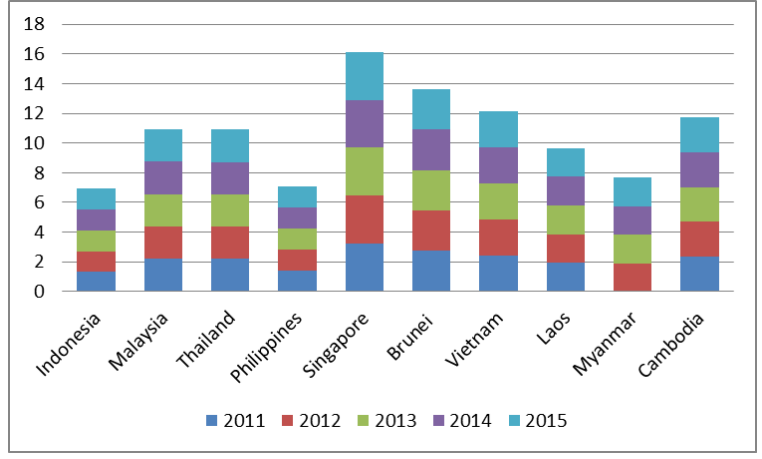

Fig. 5. Heavy Weapons Index (Period of 2011-2015).

Source: Source: Data Processing from Bonn International Center for Conversion (https://www.bicc.de/) 
From the above three figures, we can see the position of Indonesia through the index of military expenditure, military personnel and heavy weaponry. Of the three indices, Indonesia have low index, despite having a high national income and population compared to countries in thestrategic environment. From the table, Singapore provides the three highest indexes though a small country. However, this has not provided a picture of instability in the region, because it is realized that Singapore must be ready with a formidable defense, because they surrounds by big countries. Brunei and Vietnam are also depicted in a high index beyond Indonesia.

The index data of military nations in Southeast Asia is still in balance condition, except the Laos is still low. While the heavy weapon index provides a more varied picture, where Indonesia, the Philippines and Myanmar are still low, while Singapore, Brunei and Vietnam show very high heavily armaments. For the number of military personnel, the countries of Singapore, Vietnam, Thailand, and Laos, have index above Indonesia.

All these data indicate the militarization degree of a country. From the Global Military Index (can be seen in the table below), Indonesia still has militarization level below the average in Southeast Asia along with Malaysia, Philippines and Myanmar. While Singapore, Vietnam and Brunei provide a high militarization degree. Thailand, Myanmar, and Cambodia have militarized levels in the average range.

Coordinating Minister for Political, Legal and Security Affairs of Indonesian Republic, Luhut Panjaitan, as also stated that during the last fifteen years untill 2015, the defense budget is still below $1 \%$ of GDP. Compared with neighboring countries, Indonesia's defense budget is relatively smaller, whereas the area of Indonesia is much larger. The amount of defense budget is still very low where Indonesia still has to improve the quality of weapons system. Therefore, the defense budget needs to be increased gradually [9].

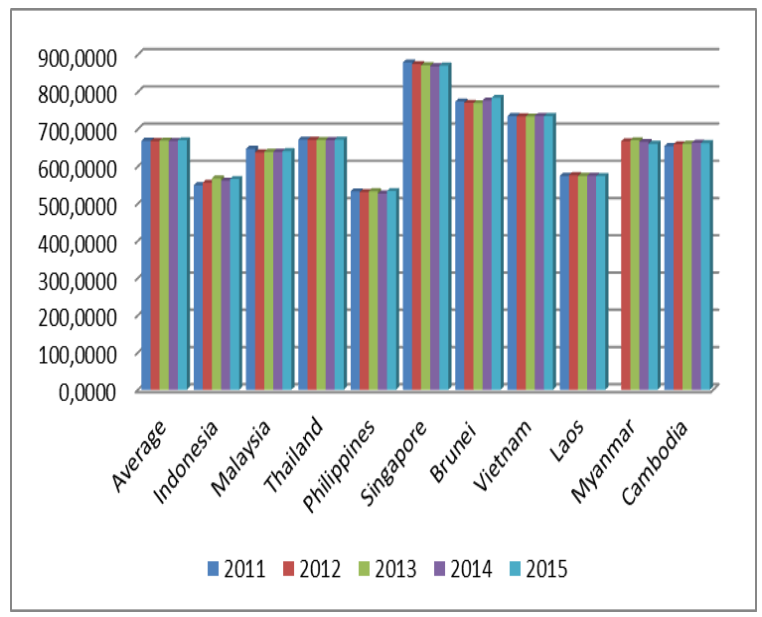

Fig. 6. Global Military Index between Countries in Southeast Asia (Period of 2011-2015). Source: Source: Data Processing from Bonn International Center for Conversion(https://www.bicc.de/)

"In many countries, excessive militarization hinders the necessary structural change of the economic and social framework conditions and enforces development deficits in its industry and agriculture. On the other hand, a low degree of militarization can be to point 
deficits in the security sector. A weak or not functioning security sector can not prevent violence and conflicts which negatively affect the population and its development as it can not succeed enforce and uphold a monopoly of violence. One result is often fragile and weak states in which economic growth and development can not prosper. These examples illustrate the dilemma of the debate. The GMI is attempting to dispel the wide assumption that a high level of militarization is bad and a low level per se good, and to contribute to a new approach on studying militarization. An assessment of the situation concerning the development of the country and regions" [10].

In South East Asia, the tensions of the territories disputes in the South China make the rise in the militarization level of the countries concerned. The GMI values of Indonesia, Vietnam, the Philippines have remained fairly constant. But it can not be ruled out that this will change in the future. Vietnam are modernizing their navy. From 2011 to 2015, Vietnam was ranked eighth in the global importers of major conventional weapons. The majority of them came from Russia; the cooperation will intensify in the coming years. Yet another interesting feature is likely to be, what impact the complete lifting of the United States' arms embargo against Vietnam, as announced in May 2016, will have on this. The embargo has existed since the end of the war. In Myanmar, Aung San Suu Kyi certainly brought high hopes to the population. But the fighting, especially in Kachin and Shan State, and the violent unrest between the Buddhist Rakhine and the Rohingya Muslimshave recently escalated. In the past year, thousands have been newly driven out by forced resettlements and violent conflicts in Rakhine, Shan and Kachin State [11].

\section{Conclusions}

The assumption of "natural balance of power" is where there is balance of power in a region that is still stable. This situation will be reflected when the military budget policy of the country for building its defense force based on its economic strength. Indonesia has the highest national income and the largest population, so naturally it is proper for large armed force, regardless of the security dilemma. Indonesia's position through military expenditure index, military personnel and heavy weaponry is still low. Despite the fact that Indonesia's military index is still in balance condition, the index of heavy weapons and military personnel is still lagging behind. From the Global Military Index, Indonesia still has militarization levels below the average in Southeast Asia, along with Malaysia, Philippines and Myanmar. While Singapore, Vietnam and Brunei provide a high militarizationdegree. Thailand, Myanmar and Cambodia have militarized levels in the average range. As a suggestion, Indonesia needs to increase its military budget along with weaponry programs especially heavy and sophisticated equipment, as well as additional reserves of military personnel.

\section{References}

[1]P. S. J. Kennedy, "Natural Balance of Power, The Balance of Power Between Countries that Promote Economic,” Fundam. Manag. J. ISSN 2540-9816, vol. 01/01, no. 1, pp. 58-71, 2016.

[2]J. Grebe, The Global Militarization Index ( GMI ) Occasional Paper February 2011, vol. February 2, no. February. 2011.

[3]J. H. Lebovic and A. Ishaq, "Military Burden, Security Needs, and Economic Growth in the Middle East,” J. Conflict Resolut., vol. 31, no. 1, pp. 106-138, 1987.

[4]P. Chatterjee, "The Classical Balance of Power Theory *," J. Peace Res., vol. 9, no. 1, pp. 51-61, 1972. 
[5]M. Sheehan, The Balance of power: History and theory, First publ. London and New York: Routledge, 2000.

[6]A. Virmani, Economic Performance, Power Potential And Global Governance: Towards A New International Order, vol. WP No.150, no. 150. 2004.

[7]S. G. J. Gregory F. Treverton, "Measuring National Power," in RAND, 2005, pp. 1-35.

[8]R. J. Green, Balance of power and the prospects for peace: the case of the Levant Monterey, California, vol. Thesis. 2002.

[9]J. Tni and P. Luhut, "Menciptakan Stabilitas Melalui Peningkatan Pertahanan dan Pemerataan Ekonomi," 2016, no. April.

[10]M. M. Mutschler, Global Militarization Index 2016. 2016.

[11]Ingrid Gabriela Hoven, Annual Report 2017. 2017. 